\title{
Penilaian Tingkah Laku Sapi Brahman Cross Selama Proses Loading dan Unloading
}

\author{
Behavior Assesment of Brahman Cross During Loading and Unloading
}

E.L. Aditia*, R. Priyanto dan A. Muhammad

Departemen Ilmu Produksi dan Teknologi Peternakan, Fakultas Peternakan, Institut Pertaninan Bogor

Email koresponden author: editlesa13@gmail.com

\begin{abstract}
Loading and unloading process may lead stress to the animal. The stress can be observed from behavior action of the animal. The aim of the study was to assess behavior during loading and unloading process. Total 24 loading groups (LG) with 11 Brahman cross cattles for each LG was observed during study. An average bodyweight of the cattle was $521 \pm 28.14 \mathrm{~kg}$. The data was analyzed descriptively with score, frequency and duration of each behavior action. The results showed that the cattle had loading time of $S$ score (very bad) and behavior score 3 (average). Meanwhile the unloading time of $T$ score (very good) and behavior score of 3 (average). Slips, jump, and fall behavior were the behavior that frequent occured during the loading and unloading process. In general, the loading process potentially stressful for cattle compare to unloading process.
\end{abstract}

Keywords: behavior, Brahman cross, loading, unloading

\section{PENDAHULUAN}

Transportasi hewan merupakan proses perpindahan ternak oleh satu atau lebih alat transportasi termasuk pemuatan (loading), pergerakan, istirahat, sampai penurunan (unloading) hewan di tempat tujuan (Adenkola 2010). Transportasi berpotensi menyebabkan stres pada ternak (Fazio dan Ferlazzo 2003). Selanjutnya stres dapat mempengaruhi aspek kesejahteraan hewan serta berpengaruh terhadap mortalitas ternak, penurunan bobot badan, serta kualitas karkas dan daging (Chambers and Grandin (2001).

Salah satu indikator untuk mengetahui stres pada ternak selama proses transportasi adalah dengan mengamati tingkah lakunya, khususnya pada saat lading dan unloading. Pengukuran tingkat stres selama proses loading dan unloading ini sangat sulit dilakukan, sehingga dibutuhkan metode pengukuran yang mudah dan tidak invasif, salah satunya adalah dengan melakukan skoring, sehingga proses penilaian aspek kesejahteraan hewan melalui indikator tingkah laku dapat lebih mudah dilakukan. Sistem skoring yang telah dikembangkan terdiri dari dua bagian, yaitu meliputi pengukuran waktu yang dibutuhkan selama proses loading dan unloading dengan menggunakan simbol huruf (T, R, A, N dan S). Selanjutnya adalah skor untuk setiap tingkah laku yang muncul dengan skor 1 sampai dengan 6 (Maria et al 2004). Kajian mengenai pengukuran tingkat stress selama proses loading dan unloading masih jarang dilakukan, sehingga penelitian ini bertujuan untuk menilai proses loading dan unloading sapi Brahman cross steer dengan memperhatikan tingkah laku yang terjadi saat proses tersebut

\section{MATERI DAN METODE}

\section{Lokasi dan Waktu}

Penelitian ini dilaksanakan di PT Elders Indonesia meliputi pengamatan di feedlot yang berlokasi di Lampung Tengah dan Rumah Potong Hewan (RPH) yang berlokasi di Kampus IPB Darmaga Bogor. Penelitian dilakukan dari bulan Februari hingga April 2018.

\section{Materi}

Total 264 ekor sapi Brahman cross (BX) dengan rataan bobot badan $521 \pm 28,14 \mathrm{~kg}$ dan kisaran umur $\mathrm{I}_{1}-\mathrm{I}_{2}$ (24-36 bulan) digunakan pada penelitian ini. Sapi BX yang digunakan didominasi oleh sapi jantan kebiri (steer) dan sebagian kecil sapi dara (heifer).

\section{Prosedur}

\section{Proses Transportasi Sapi dari PT Elders Indonesia Hingga RPH IPB}

Proses transportasi sapi dari feedlot PT Elders Indonesia di Lampung menuju Rumah Potong Hewan IPB meliputi 3 tahapan utama yaitu :

\section{a. Persiapan Moda Transportasi}

Moda transportasi yang digunakan ialah truk jenis fuso dengan panjang 8,20 $\mathrm{m}$ dan lebar 2,44 m. Truk dilengkapi jaring pada bagian atas truk serta alas penutup bak truk (bedding) untuk menghindari ternak tergelincir selama perjalanan. Truk yang digunakan 
dilengkapi dokumen perjalanan yang berisikan jumlah ternak, bobot ternak, serta bobot keseluruhan.

b. Persiapan sapi dan pemuatan sapi (loading)

Sapi-sapi yang akan dikirimkan, digiring dari pen menuju crowding pen melalui cattle race. Setelah berada di crowding pen sapi digiring menuju gangway dan cattle crush untuk dilakukan proses penimbangan. Setelah ditimbang, sapi-sapi tersebut dikumpulkan di collecting pen sebelum naik ke truk. Proses selanjutnya adalah pemuatan sapi dengan cara menggiring sapi menuju truk yang sudah berada di loading point (Gambar 1). Pengertian istilah fasilitas yang berada di PT Elders Indonesia tersaji pada Tabel 1.

\section{c. Penurunan sapi (unloading)}

Proses penurunan sapi dilakukan di RPH PT Elders Indonesia yang berada di kampus IPB Dramaga Bogor. Penurunan sapi dilakukan dengan cara truk menuju loading ramp. Selanjutnya sapi digiring melalui gang way menuju kandang penampungan (holding yard) tanpa adanya proses penimbangan (Gambar 2).

Proses loading dan unloading dalam pengamatan memiliki beberapa indikator penilaian terhadap tingkah

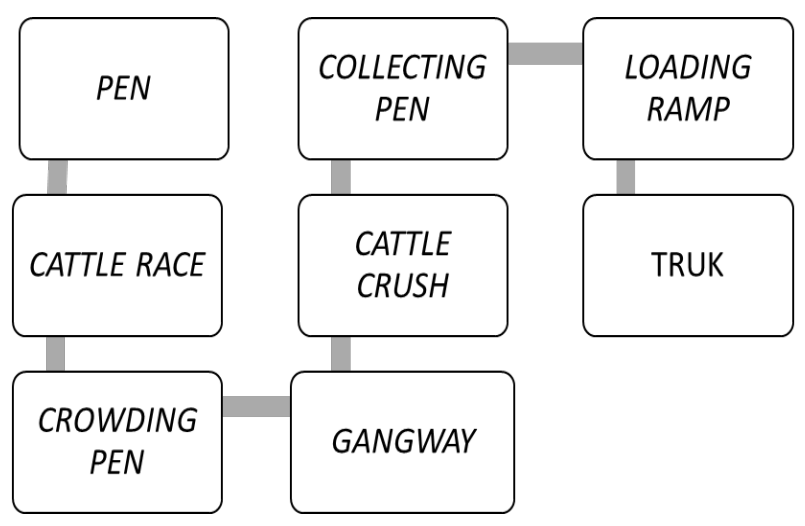

Gambar 1. Skema proses loading di PT Elders Indonesia

Tabel 1. Istilah fasilitas yang digunakan di PT Elders Indonesia

\begin{tabular}{ll}
\hline Fasilitas & Definsi \\
\hline Pen & Kandang pemeliharaan penggemukan \\
Cattle race & $\begin{array}{l}\text { Jalur yang dilalui sapi untuk proses loading } \\
\text { dan unloading }\end{array}$ \\
Crowding pen & $\begin{array}{l}\text { Kandang penampungan sementara sebelum } \\
\text { proses penimbangan }\end{array}$ \\
Holding yard & $\begin{array}{l}\text { Kandang penampungan sementara sebelum } \\
\text { proses pemotongan di RPH }\end{array}$ \\
Gangway & $\begin{array}{l}\text { Jalur sapi diantara crowding pen dengan cattle } \\
\text { crush }\end{array}$ \\
Cattle crush & $\begin{array}{l}\text { Tempat penimbangan, penanganan kesehatan } \\
\text { dan pemeriksaan kebuntingan sapi }\end{array}$ \\
Coleccting pen & $\begin{array}{l}\text { Kandang penampungan sementara sebelum } \\
\text { proses pemuatan kedalam moda transportasi }\end{array}$ \\
Loading ramp & Fasilitas penaikan dan penurunan ternak \\
\hline
\end{tabular}

Sumber: Troxel dan Gadberry (2015).

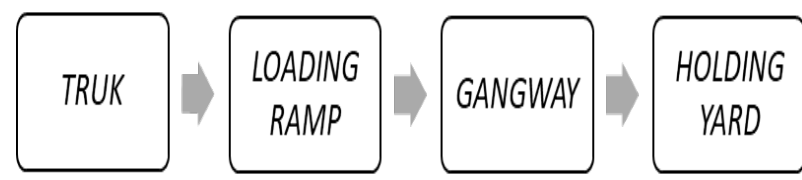

Gambar 2. Skema proses unloading di PT Elders Indonesia

laku, yang selanjutnya bobot indikator ini digunakan untuk menghitung nilai tingkah laku sapi selama proses loading dan unloading. Indikator dan bobot penilaian tingkah laku tersebut tersaji pada Tabel 2.

Tabel 2. Indikator dan bobot penilaian tingkah laku selama proses loading dan unloading

\begin{tabular}{lc}
\hline Indikator & Bobot penilaian \\
\hline Fall (jatuh) & 1 \\
Revesal (sapi berubah arah ) & 1 \\
Aggressive boult (tingkah laku agresif) & 1 \\
Mount (menaiki ternak lainnya) & 2 \\
Balks (berhenti sejenak lebih dari 10 detik) & 1 \\
Jump (melompat) & 1 \\
Slips (terpeleset) & 0,5
\end{tabular}

Sumber: María et al. (2004)

\section{Analisis Data}

Hasil penelitian terhadap proses loading dan unloading dalam memenuhi kesejahteraan hewan dianalisis secara deskriptif berdasarkan nilai yang didapat. Penilaian dilakukan oleh pengamat secara objektif dengan cara menetapkan nilai berdasarkan hasil perhitungan nilai proses loading dan unloading. Penilaian pada proses loading dan unloading dilakukan pada tiap loading group (LG). Cara penetapan nilai pada proses loading dan unloading tersaji pada Tabel 3.

Penentuan nilai terbobot pada parameter 3 dan 6 berdasarkan jumlah nilai pada setiap kejadian ternak dengan skor penilaian 1 "sangat baik" sampai 5 "sangat buruk" dan interval jumlah waktu pada tiap proses yang terjadi dengan skor penilaian T "sangat baik" sampai S "sangat buruk" yang tersaji pada Tabel 4.

\section{HASIL DAN PEMBAHASAN}

Proses Loading dan Unloading

Proses loading dan unloading merupakan tahapan proses transportasi yang sangat penting. Tahapan ini merupakan tahapan yang dapat memicu ternak menjadi stress. Faktor-faktor penyebab stress dapat diminimalisir dengan meningkatkan sistem logistik dengan penanganan yang baik (Gebresenbet 2003). Durasi merupakan salah satu faktor pemicu sress. Maria et al. (2004) mengatakan semakin lama durasi proses loading dan unloading maka semakin tinggi tingkat stress yang dialami ternak tersebut. Durasi waktu proses loading di PT Elders Indonesia tersaji pada Tabel 6.

Hasil penelitian menjukkan bahwa durasi waktu proses loading yang didapat di Tabel 5 menunjukkan 
Tabel 3. Penetapan nilai pada proses loading dan unloading

\begin{tabular}{|c|c|c|c|c|}
\hline \multicolumn{2}{|l|}{ No. } & \multicolumn{3}{|c|}{ Parameter } \\
\hline 1 & \multicolumn{3}{|c|}{ Loading groups (LG) } & Menghitu \\
\hline 2 & \multicolumn{3}{|l|}{ Loading time } & $\begin{array}{l}\text { Total wal } \\
\text { hingga te }\end{array}$ \\
\hline 3 & \multicolumn{3}{|c|}{ Unloading time } & $\begin{array}{l}\text { total wak } \\
\text { terakhir } \mathrm{n}\end{array}$ \\
\hline 4 & \multicolumn{3}{|c|}{$\begin{array}{l}\text { Penilaian lama waktu loading atau unloading } \\
\text { yang terjadi }\end{array}$} & $\begin{array}{l}\text { Berdasark } \\
\text { ditetapkar }\end{array}$ \\
\hline 5 & \multicolumn{3}{|c|}{ Kejadian saat proses loading dan unloading } & $\begin{array}{l}\text { Tiap keja } \\
\text { dijumlahk }\end{array}$ \\
\hline 6 & \multicolumn{3}{|c|}{$\begin{array}{l}\text { Rata-rata kejadian saat proses loading dan } \\
\text { unloading }\end{array}$} & Jumlah c \\
\hline 7 & \multicolumn{3}{|c|}{ Penilaian untuk kejadian } & $\begin{array}{l}\text { Berdasa } \\
\text { interval }\end{array}$ \\
\hline \multicolumn{5}{|c|}{ Sumber: María et al. (2004) } \\
\hline \multicolumn{5}{|c|}{$\begin{array}{l}\text { Tabel 4. Skor penilaian waktu dan kejadian loading atau } \\
\text { unloading }\end{array}$} \\
\hline \multicolumn{2}{|c|}{$\begin{array}{l}\text { Waktu loading atau } \\
\text { unloading tiap sapi } \\
\text { (menit) }\end{array}$} & & $\begin{array}{l}\text { Kejadian loading } \\
\text { atau unloading tiap } \\
\text { sapi }\end{array}$ & Skor \\
\hline \multicolumn{2}{|l|}{$<1$} & $\mathrm{~T}$ & 0 & 1 \\
\hline \multicolumn{2}{|c|}{$1-2$} & $\mathrm{R}$ & $0,00-0,50$ & 2 \\
\hline \multicolumn{2}{|c|}{$2-3$} & A & $0,50-1,0$ & 3 \\
\hline \multicolumn{2}{|c|}{$3-4$} & $\mathrm{~N}$ & $1,0-1,5$ & 4 \\
\hline \multicolumn{2}{|l|}{$>4$} & $\mathrm{~S}$ & $1,5-\leq 2,0$ & 5 \\
\hline
\end{tabular}

Sumber: María et al. 2004

Tabel 5. Contoh perhitungan nilai pada proses loading dan unloading

\begin{tabular}{|c|c|}
\hline Parameter & Perhitungan \\
\hline Loading group (LG) & 8 ekor \\
\hline $\begin{array}{l}\text { Waktu loading untuk } \\
\text { grup tersebut (LTG) }\end{array}$ & 20 menit \\
\hline $\begin{array}{l}\text { Waktu loading per } \\
\text { individu ternak (LT) }\end{array}$ & $\mathrm{LT}=\mathrm{LTG} / \mathrm{LG}=2,5$ minutes \\
\hline $\begin{array}{l}\text { Skor huruf untuk } \\
\text { waktu loading (LN) }\end{array}$ & $\begin{array}{l}\text { LT antara 2- } 3 \text { menit, skor huruf untuk } \\
\text { waktunya adalah A }\end{array}$ \\
\hline $\begin{array}{l}\text { Jumlah angka ke- } \\
\text { jadian tingkah laku } \\
\text { (BNG) }\end{array}$ & $\begin{array}{l}1 \text { mount }(2 \text { points }), 2 \text { balks ( } 2 \text { points }) \text {, } \\
3 \text { slips }(1,5 \text { points }) \mathrm{BNG}=5,5 \text { points }\end{array}$ \\
\hline $\begin{array}{l}\text { Kejadian tingkah laku } \\
\text { per individu }(\mathrm{BN})\end{array}$ & $\mathrm{BN}=\mathrm{BNG} / \mathrm{LG}=5-5 / 8=0,69 \mathrm{BN}$ \\
\hline $\begin{array}{l}\text { Skor angka untuk } \\
\text { tingkah laku(LB) }\end{array}$ & BN antara $0,5-0,75$ maka LBnya 3 \\
\hline $\begin{array}{l}\text { Skor loading keselu- } \\
\text { ruhan }\end{array}$ & A-3 yang berarti (sedang) \\
\hline
\end{tabular}

Sumber: María et al. 2004

bahwa durasi waktu loading paling cepat adalah 61 menit dan sebaliknya waktu loading paling lama yaitu 72 menit. Rata-rata waktu total pada proses loading yaitu 66,87 menit dan apabila dihitung tiap ekornya masing masing sapi memiliki waktu loading dengan rata rata 6,07 menit. Hal ini

menunjukan bahwa durasi waktu loading dalam penenelitian ini sangat buruk dan tidak sesuai dengan peryataan Maria et al. (2004) yang menyatakan bahwa waktu yang sangat baik dalam proses loading adalah kurang dari 1 menit dan sebaliknya waktu yang sangat buruk ialah lebih dari 4 menit ekor ${ }^{-1}$. Durasi waktu loading sangat buruk dalam penelitian ini dikarenakan perhitungan waktu dimulai saat sapi-sapi tersebut digiring dari kandang penggemukkan dan melewati berbagai proses diantaranya proses penimbangan sehingga waktu yang diperlukan cukup lama. Durasi waktu proses loading memiliki nilai $\mathrm{T}$ atau sangat baik jika perhitungan durasi dimulai dari collecting pen tanpa adanya proses penimbangan. Durasi Waktu proses unloading yang berada di PT Elders Indonesia dapat dilihat pada Tabel 7.

Hasil pengamatan waktu proses unloading pada Tabel 6 menunjukkan bahwa waktu paling cepat adalah 36 detik sebaliknya untuk waktu paling lambat yaitu 128 detik atau 2 menit 8 detik dan memiliki rata rata waktu unloading 60,08 detik dan apabila dihitung tiap ekor sapi, waktu unloading yang diperlukan yaitu 5,46 detik. Hasil ini menunjukkan bahwa waktu unloading di PT Elders Indonesia sangat baik dan sesuai dengan yang dinyatakan oleh Maria et al. (2004) bahwa proses loading dan unloading yang baik yaitu masing-masing sapi memiliki nilai waktu di bawah 1 menit. Berdasarkan perhitungan durasi waktu, proses unloading memiliki skor waktu lebih baik dibandingkan proses loading. Hal ini disebabkan pada proses unloading, sapi dari truk langsung digiring menuju tempat penampungan sapi tanpa dilakukannya proses penimbangan sapi. Selain itu jarak dari loading point menuju tempat penampungan sapi lebih dekat sehingga waktu yang dibutuhkan pada proses unloading cenderung lebih cepat dengan rata-rata waktu 5,46 detik perekor atau memiliki nilai $\mathrm{T}$.

\section{Tingkah Laku Selama Proses Loading dan Unloading}

Salah satu upaya untuk menilai ternak tersebut stres dapat dilihat dari tingkah laku ternak yang terjadi. Terdapat beragam tingkah laku ternak sebagai ekspresi dalam menghadapi bermacam-macam kondisi lingkungan berdasarkan penelitian yang telah dilakukan, tingkah laku yang terjadi saat proses loading dan unloading di PT Elders 
Tabel 6. Rataan durasi waktu proses loading (Menit)

\begin{tabular}{lcccccccc}
\hline & Pen-CrP & CrP-CP & CP-Truk & Total & Ternak/LG & Waktu/ individu & Score \\
\hline Rataan & 6,33 & 58,79 & 1,75 & 66,87 & 11 & 6,07 & $\mathrm{~S}$ \\
Maks. & 9 & 61 & 3 & 72 & 11 & 6,54 & $\mathrm{~S}$ \\
Min & 4 & 55 & 1 & 61 & 11 & 5,54 & $\mathrm{~S}$ \\
\hline
\end{tabular}

Ket: CrP: Crowding Pen, CP: Collecting Pen, LG: Loading Group.

Tabel 7. Rataan waktu proses unloading (Detik)

\begin{tabular}{lcccc}
\hline & $\begin{array}{c}\text { Unloading } \\
\text { time }\end{array}$ & $\begin{array}{c}\text { Ternak/ } \\
\text { unloading } \\
\text { group }\end{array}$ & $\begin{array}{c}\text { Waktu/ } \\
\text { individu } \\
\text { (detik) }\end{array}$ & Score \\
\hline Rataan & 60,08 & 11 & 5,46 & $\mathrm{~T}$ \\
Maks. & 128 & 11 & 11,63 & $\mathrm{~T}$ \\
Min & 36 & 11 & 3,27 & $\mathrm{~T}$ \\
\hline
\end{tabular}

Indonesia memiliki frekuensi yang beragam. Tingkah laku slips atau terpeleset merupakan tingkah laku yang sering muncul sedangkan tingkah laku yang minim muncul atau jarang muncul yaitu perilaku mount atau menaiki teman. Persentase tingkah laku dihitung berdasarkan jumlah tingkah laku (kejadian jatuh, berubah arah, agresif, berhenti sejenak, menaiki teman, lompat, dan terpeleset) yang dinotasikan sebagai frekuensi dibagikan total jumlah loading group (LG) yakni berjumlah 24 .

\section{Jatuh (fall)}

Jatuh merupakan salah satu indikator untuk mengevaluasi kesejahteraan hewan dan tingkat stress pada saat proses loading dan unloading. Tingkah laku ini menjadi indikator yang penting karena apabila terdapat satu ekor sapi yang jatuh maka akan membuat kegaduhan di sekitarnya dan membuat ternak lainnya menjadi cemas. Dalam pengamatan ini ternak dapat dikatakan jatuh apabila keempat kaki sapi tidak dapat menopang tubuhnya. Berikut persentase kejadian jatuh yang terjadi pada saat proses loading dan unloading di PT. Elders Indonesia dapat dilihat di Tabel 8.

Frekuensi jatuh yang tercatat pada saat proses loading dan unloading yakni 0 s.d 3 yang menunjukkan jumlah kejadian jatuh. Tidak adanya kejadian jatuh atau pada frekuensi 0 , proses loading memiliki persentase LG lebih besar yakni 58,33\% dibandingkan proses unloading yakni $16,67 \%$. Kejadian jatuh frekuensi 1 dan 2 lebih banyak terjadi pada proses unloading dibandingkan proses loading, sementara untuk kejadian jatuh frekuensi 3 pada proses loading dan unloading memiliki persentase LG yang sama.

Tabel 8. Persentase tingkah laku jatuh

\begin{tabular}{lcc}
\hline Frekuensi & \multicolumn{2}{c}{ Persentase LG (\%) } \\
\cline { 2 - 3 } & Loading & Unloading \\
\hline 0 & 58,33 & 16,67 \\
1 & 25 & 45,83 \\
2 & 8,33 & 29,16 \\
3 & 8,33 & 8,33 \\
\hline
\end{tabular}

Faktor-faktor yang mempengaruhi tingkah laku jatuh pada proses loading dan unloading antara lain lantai pintu belakang truk yang terlalu licin, ternak yang cemas karena berada dilingkungan yang baru, kelelahan dalam perjalanan dan kehilangan keseimbangan. Hal ini sesuai dengan pernyataan Bullita (2015) yaitu ternak akan merasa gugup dan cemas jika berada di lingkungan yang baru yang akan menimbulkan kepanikan dan hilangnya keseimbangan yang mengakibatkan ternak terjatuh. Bullita (2015) juga mengatakan bahwa proses transportasi menyebabkan kelelahan otot pada ternak yang megakibatkan ternak bergoyang dan hilangnya keseimbangan.

\section{Berubah arah (Reversals)}

Berubah arah atau reversals merupakan salah satu indikator untuk mengevaluasi kesejahteraan hewan dan tingkat stres pada ternak saat proses loading dan unloading. Indikator ini dapat menyebabkan terhambatnya proses loading karena menyebabkan ternak lainnya terhalang untuk memasuki truk dan menyebabkan kegaduhan disekitarnya. Sapi dapat dikatakan berubah arah atau reversals jika ternak tersebut berbalik arah dari jalur gangway. Persentase berubah arah (reversals) saat proses loading dan unloading dapat dilihat di Tabel 9.

Tabel 9. Persentase berubah arah (reversals)

\begin{tabular}{lc}
\hline Frekuensi & Persentase LG (\%) \\
\cline { 2 - 2 } & Loading \\
\hline $0-2$ & 58,33 \\
$3-5$ & 16,66 \\
$6-8$ & 4,16 \\
\hline
\end{tabular}

Frekuensi berubah arah hanya terjadi pada proses loading, sementara pada proses unloading tidak terjadi. Kejadian berubah arah dibagi menjadi 3 yakni 0-2, 3-5, dan 6-8. Interval tersebut menunjukkan jumlah kejadian berubah arah yang dihitung berdasarkan metode quartil dari data yang ada. Persentase LG yang mengalami kejadian berubah arah 0 -2 sebesar 58,33\%, sementara 3-5 sebesar 16,66\% dan 6-8 sebesar $4,16 \%$. Faktor-faktor yang mempengaruhi terjadinya tingkah laku ini ialah ternak cemas karena berada di lingkungan yang baru.

\section{Agresif}

Agresif merupakan salah satu indikator pengamatan untuk mengevaluasi kesejahteraan hewan dan tingkat stress yang terjadi saat proses loading dan unloading.Dalam pengamatan ini ternak dapat dikatakan berperilaku agresif apabila suatu individu ternak dengan individu ternak lain saling melukai atau bersikap agonistik. Persentase perilaku 
agresif saat proses loading dan unloading dapat dilihat pada Tabel 10.

Tabel 10. Persentase perilaku agresif

\begin{tabular}{lc}
\hline Frekuensi & Persentase LG $(\%)$ \\
\cline { 2 - 2 } & Loading \\
\hline 0 & 87,5 \\
3 & 4,16 \\
7 & 8,33 \\
\hline
\end{tabular}

Frekuensi agresif hanya terjadi saat proses loading sementara pada proses unloading tidak terjadi. Kejadian agresif dibagi menjadi 3 frekuensi yakni 0, 3, dan 7. Interval tersebut menunjukkan jumlah kejadian agresif yang dihitung berdasarkan metode quartile dari data yang ada. Persentase LG yang mengalami kejadian agresif 0 atau tidak terjadi sebesar $87,5 \%$ sementara frekuensi 3 sebesar 4,16\% dan 7 sebesar $8,33 \%$. Faktor-faktor yang menyebabkan terjadinya perilaku agresif antara lain ialah ternak stress dan merasa memiliki ancaman, ternak stress dapat dilihat dari proses penanganan dan penimbangan saat proses tersebut sapi merasa cemas dan merasa tertekan sehingga perilaku agresif dapat terjadi.

\section{Menaik (mount)}

Menaik atau mount merupakan salah satu indikator untuk mengevaluasi kesejahteraan hewan atau tingkat stress yang terjadi saat proses loading dan unloading. Tingkah laku ini menjadi indikator yang penting karena perilaku ini dapat menyebabkan kegaduhan di sekitarnya dan membuat ternak lainnya merasa terancam dan cemas. Persentase prilaku menaik atau mount dapat dilihat pada Tabel 11.

Tabel 11. Persentase prilaku menaik (mount) proses loading dan unloading

\begin{tabular}{lcc}
\hline Frekuensi & \multicolumn{2}{c}{ Persentase LG (\%) } \\
\cline { 2 - 3 } & Loading & Unloading \\
\hline 0 & 95,83 & 87,5 \\
1 & 4,16 & 8,33 \\
2 & & 4,16 \\
\hline
\end{tabular}

Berdasarkan Tabel 11, sebesar 95,83\% tidak terdapat kejadian menaik pada LG.Hal ini menunjukkan bahwa kejadian menaik (mount) terjadi sangat minim atau sangat sedikit. Bulita (2015) mengatakan bahwa perilaku menaik atau mount terjadi karena efek stres ternak karena berada pada lingkungan yang baru. Hasil pengamatan perilaku menaik (mount) saat proses unloading memiliki sedikit perbedaan dengan proses loading yaitu frekuensi yang terjadi pada proses unloading memiliki interval 0 hingga 2 dengan persentase tertinggi terjadi pada frekuensi 0 atau tidak munculnya kejadian menaik yaitu $87,5 \%$ dan terendah pada frekuensi 2 dengan persentase 4,16\%. Hal ini menunjukkan bahwa perilaku menaik atau mount yang terjadi saat proses unloading memiliki persentase yang tidak jauh berbeda dengan proses loading yaitu perilaku menaik atau mount sangat minim terjadi.

\section{Berhenti sejenak (balks)}

Berhenti sejenak atau balks merupakan salah satu indikator yang diamati pada saat proses loading dan unloading untuk mengetahui tingkat stres dan kesejahteraan hewan. Dalam pengamatan ini suatu ternak dapat dikatakan mengalami perilaku berhenti sejenak atau balks jika ternak tersebut berhenti lebih dari 10 detik. Persentase perilaku berhenti sejenak (balks) saat proses loading dan unloading dapat dilihat pada Tabel 12.

Tabel 12. Persentase perilaku berhenti sejenak (Balks)

\begin{tabular}{lc}
\hline Frekuensi & Persentase LG (\%) \\
\cline { 2 - 2 } & Loading \\
\hline $0-2$ & 41,66 \\
$3-5$ & 33,33 \\
$6-8$ & 8,33 \\
$9-10$ & 16,66 \\
\hline
\end{tabular}

Frekuensi berhenti sejenak hanya terjadi saat proses loading sementara pada proses unloading tidak terjadi. Kejadian berhenti sejenak dibagi menjadi 4 frekuensi yakni 0-2, 3-5, 6-8 dan 9-11. Interval tersebut menunjukkan jumlah kejadian agresif yang dihitung dari data yang ada. Persentase LG yang mengalami kejadian agresif 0-2 sebesar 41,66\% sementara frekuensi 3-5 sebesar 33,33\%, 6-8 sebesar 8,33 \%, dan 9-11 sebesar 16,66\%. Faktor-faktor yang mempengaruhi terjadinya perilaku berhenti sejenak atau balks antara lain ialah adanya jarak yang sedikit tinggi antara loading point dengan pintu belakang truk sehingga ternak ternak tersebut enggan untuk menaiki truk tersebut. Grandin (1980) mengatakan bahwa sapi akan mengalami balks apabila terdapat perbedaan lantai selama sapi sapi itu bergerak. Selain itu Bullita (2015) juga mengatakan bahwa ternak akan sedikit cemas dan gugup jika berada di lingkungan yang baru.

\section{Lompat (Jump)}

Lompat merupakan salah satu indikator yang diamati dalam pengamatan ini untuk mengevaluasi tingkat stress dan kesejahteraan hewan. Persentase tingkah laku lompat saat proses loading dan unloading terdapat pada Tabel 13.

Hasil pengamatan tingkah laku melompat pada saat proses loading dan unloading memiliki interval 0-1, 2-3 dan 4-5. Pada proses loading persentase tertinggi berada pada frekuensi 2-3 yaitu $62.5 \%$ dan sebaliknya untuk persentase terkecil berada pada frekuensi $0-1$ yaitu $16,66 \%$ sedangkan untuk proses unloading persentase terbesar juga berada pada frekuensi 2-3 yaitu 41,66\% dan sebaliknya untuk persentase terkecil juga berada pada frekuensi 0-1 yaitu

Tabel 13. Persentase Tingkah Laku Lompat

\begin{tabular}{lcc}
\hline Frekuensi & \multicolumn{2}{c}{ Persentase LG $(\%)$} \\
\cline { 2 - 3 } & Loading & Unloading \\
\hline $0-1$ & 16,66 & 20,83 \\
$2-3$ & 62,5 & 41,66 \\
$4-5$ & 20,83 & 37,5 \\
\hline
\end{tabular}


20,83\%. Hal ini menunjukkan bahwa prilaku melompat sering terjadi saat proses loading maupun proses unloading. Perilaku melompat sering terjadi saat sapi mulai memasuki truk. Hal ini disebabkan adanya jarak yang berbeda antara loading point dengan pintu belakang truk, selain itu perilaku melompat juga terjadi dikarenakan sapi merasa terancam dan cemas akibat adanya penggiringan dari belakang oleh penggiring. Hal tersebut sesuai dengan pendapat yang menyatakan bahwa proses loading dan unloading dapat menyebabkan stres dikarenakan ternak cemas dan gugup akibat adanya penanganan penggiringan (Genbenset 2003).

\section{Terpeleset (slips)}

Terpeleset merupakan salah satu indikator yang diamati untuk mengevaluasi tingkat kesejahteraan hewan dan tingkat stres saat proses loading dan unloading. Persentase tingkah laku terpeleset atau slips dapat dilihat pada Tabel 14.

Hasil pengamatan menunjukkan bahwa perilaku terpeleset atau slips saat proses loading memiliki frekuensi dengan interval 0-1, 2-3, dan 4-5 dengan nilai persentase

Tabel 14. Persentase Perilaku Terpeleset (slips) proses loading

\begin{tabular}{lc}
\hline Frekuensi & Persentase LG (\%) \\
\cline { 2 - 2 } & Loading \\
\hline $0-1$ & 20,83 \\
$2-3$ & 50 \\
$4-5$ & 2,16 \\
\hline
\end{tabular}

terbesar berada pada frekuensi 2-3 yaitu 50\% dan sebaliknya untuk persentase terkecil berada pada frekuensi 4-5 yaitu 2,16\%.Hal ini menjelaskan bahwa tingkah laku terpeleset atau slips saat proses loading sangat sering terjadi. Beberapa faktor yang mempengaruhi terjadinya perilaku ini ialah lantai pintu belakang truk yang licin sehingga ternak mudah terpeleset selain itu loading point yang menanjak dan sedikit basah akibat urine sapi tersebut. Sapi akan mengeluarkan air urine akibat rasa cemas dan gugup akibat berada pada lingkungan yang baru (Bullita 2015). Persentase tingkah laku terpeleset (slips) pada proses unloading dapat dilihat pada Tabel 15 .

Hasil pengamatan menunjukkan bahwa perilaku terpeleset atau slips saat proses unloading memiliki frekuensi 0-2, 3-5, dan 6-8. Persentase tertinggi berada pada frekuensi 3-5 yaitu $75 \%$ dan sebaliknya untuk persentase terendah berada pada frekuensi 0-2 dan 6-8 yaitu masing masing $12,5 \%$. Hal ini menunjukkan adanya peningkatan frekuensi dan persentase dari proses loading. Hal tersebut dikarenakan adanya pengaruh stres yang terjadi akibat proses transportasi.

Tabel 15. Persentase perilaku terpeleset (slips) proses unloading

\begin{tabular}{lc}
\hline Frekuensi & Persentase LG (\%) \\
\cline { 2 - 2 } & Unloading \\
\hline $0-2$ & 12,5 \\
$3-5$ & 75 \\
$6-8$ & 12,5 \\
\hline
\end{tabular}

Selama transportasi, ternak akan mengalami kelelahan otot sehingga mengakibatkan hilangnya keseimbangan tubuh ternak (Bullita 2015). Selain itu faktor yang lainnya ialah pintu belakang truk yang licin akibat air urine sapi. Pintu belakang truk terbuat dari besi dsn tidak bergerigi sehingga pintu belakang truk jika terkena air akan menjadi licin.

Rataan skor keseluruhan proses loading dan unloading

Skor keseluruhan didapat berdasarkan perhitungan rata rata skor durasi waktu dan skor tingkah laku. Rataan skor keseluruhan untuk proses loading ialah S3 yang berartikan bahwa skor untuk durasi waktu memiliki nilai yang sangat buruk sedangkan skor untuk tingkah laku memiliki nilai 3 yang dapat diartikan bahwa tingkah laku pada proses loding memiliki nilai yang sedang. Proses unloading memiliki nilai rataan skor keseluruhan T3 yang berartikan bahwa skor untuk durasi waktu memiliki nilai yang sangat bagus sedangkan untuk tingkah laku memiliki nilai sedang.

\section{KESIMPULAN}

Evaluasi proses loading dan unloading di PT Elders Indonesia menunjukkan bahwa proses loading memiliki nilai S (sangat buruk) untuk durasi waktu dan nilai 3 (sedang) untuk tingkah laku sedangkan proses unloading memiliki nilai $\mathrm{T}$ (sangat baik) untuk durasi waktu dan nilai 3 (sedang) untuk tingkah laku. Nilai tersebut menunjukkan bahwa proses loading lebih berpotensi menimbulkan stress dibandingkan proses unloading

\section{DAFTAR PUSTAKA}

Adenkola AY, Ayo JO. 2010.Physiological and behavioural responses of livestockto road transportation stress: a review. African Journal Of Biotechnology 9(31).

Bulita SF, Aradom S, Gebrenset G. 2015.Effect of transport time upto 12 hours on welfare of cows and bulls. Journal of Service andManagement 8: 161-182 .

Chambers PG, Grandin T. 2001. Guidelines for Humane Handling, Transport and Slaughter of Livestock. Humane Society International, Food and Agriculture Organization of The United Nation Regional Office for Asia and The Pacific.

Fazio E dan Ferlazzo A. 2003. Evaluation of stress during transport. Veterinary Reasearch27(1): 519-524.

Gebresenbet G. and Nilsson C. 2003. Assessment of air quality in commercial cattle transport vehiclein swedish summer and winter conditions. German Veterinary Journal 110: 100-104.

Grandin T. 1980. Bruises and carcass damage. International Journal for the Study of Animal Problems 1(2): 121137.

KEMENTAN. 2015. Peraturan Menteri tentang instalasi karantina hewan. Jakarta (ID). KEMENTAN RI.

María GA, Villaroel M, Chacón G, Gebresenbet G. 2004. Scoring system for evaluating the stress to cattle of commercial loading and unloading. The Veterinary Record 154: 818 - 820 .

Troxel T R, Gadberry S. 2015. Cattle Working Facilities. Arkansas (US). University Of Arkansas. 